\title{
PROFIL LABORATORIUM DAN KOMPETENSI GURU PENGELOLA LABORATORIUM IPA/BIOLOGI SMP NEGERI DI KOTA PEKANBARU TAHUN AJARAN 2016/2017
}

\author{
Desti $^{1^{*}}$, Adelina Maryanti ${ }^{1}$ \\ ${ }^{1}$ Program Studi Pendidikan Biologi FKIP Universitas Islam Riau, Jl. Kaharuddin Nasution 113 Pekanbaru Riau \\ Indonesia 28284
}

Korespondensi Author: nurleli3497@gmail.com (Leli)

\section{INFO ARTIKEL}

Histori Artikel

Received 23 Febuari 2019

Revised 18 Juli 2019

Accepted 20 Juli 2019

Published 13 Agustus 2019

\section{Keywords:}

Laboratory Profile, Teacher Management Competency, State Junior High School, Biology Laboratory

\begin{abstract}
Research of laboratory profiles and the competence of laboratory management teachers is very important. This study aims to provide information about laboratory descriptions and teacher competencies in the management of science/biology laboratories so that they can be used as sustainable evaluation materials. The results of the research have been obtained through direct observation in the science/biology Laboratory at the state junior high school in Pekanbaru with a reference observation sheet based on the Minister of Education Regulation No. 24 of 2007 concerning the facilities and infrastructure of science laboratories. The results showed that the average percentage of science/biology laboratory equipment was $85.43 \%$ and the description of the science/biology laboratory was under the Minister of Education Regulation No. 24 of 2007 concerning science/biology laboratory facilities and infrastructure for junior high schools. Based on the results of research on the competencies of teachers of science/biology laboratory management, it can be concluded that the competence of laboratory management teachers is in the category of sufficiently competent to highly competent categories. Overall, the average competency of management teachers is $81.62 \%$ which is included in the competent category. It's showed generally the teachers who manage the science/biology Laboratories at state junior high schools in Pekanbaru have been able to manage the laboratory well.
\end{abstract}

Copyright (C) 2019 Universitas Negeri Medan. Artikel Open Access dibawah lisensi CCBY-4.0 (https://creativecommons.org/licenses/by/4.0)

\section{How to Cite:}

Desti \& Maryanti, A. (2019). Profil Laboratorium dan Kompetensi Guru Pengelola Laboratorium IPA/Biologi SMP Negeri di Kota Pekanbaru Tahun Ajaran 2016/2017. Jurnal Pelita Pendidikan, 7(2), 064-072. 


\section{PENDAHULUAN}

Pada dasarnya, pendidikan sains menekankan pada penyediaan pengalaman langsung untuk mengembangkan kompetensi sehingga siswa dapat menjelajahi dan memahami dunia alam secara ilmiah. Umumnya SMPN di Pekanbaru tidak memiliki laboratorium dan teknisi laboratorium, sehingga pengelola atau kepala laboratorium IPA kewalahan dalam mengurus laboratorium sains. Selain itu, berdasarkan hasil pengamatan diperoleh bahwa banyak ruang laboratorium digunakan sebagai ruang kelas untuk proses pembelajaran, tidak dimaksudkan untuk kegiatan praktikum.

Alat dan sumber belajar, walaupun fungsinya sebagai alat bantu, akan tetapi memiliki peran yang tidak kalah pentingnya. Dalam kemajuan teknologi seperti sekarang ini memungkinkan siswa dapat belajar dari mana saja dan kapan saja dengan memanfaatkan hasil-hasil teknologi. Oleh karena itu, peran dan tugas guru bergeser dari peran sebagai sumber belajar menjadi peran sebagai pengelola sumber belajar. Melalui penggunaan berbagai sumber itu diharapkan kualitas pembelajaran akan semakin meningkat (Sanjaya, 2010). Di bagian inilah laboratorium mengambil peranan yang sangat penting. Untuk membangun pengetahuan itu siswa tidak dapat hanya pasif menerima, melainkan juga harus "bertindak" terhadap hal-hal yang dihadapinya dan yang menjadi perhatian itu. Laboratorium sains memberikan banyak sekali kesempatan bagi siswa untuk "bertindak" terhadap hal-hal yang sedang dipelajarinya, dan yang sedang diperhatikannya (Kertiasa,2006).

Agar laboratorium dapat berfungsi sesuai dengan maksud pengadaannya, laboratorium perlu digunakan dan dikelola dengan sebaikbaiknya. Tanpa digunakan dan dikelola dengan baik pengadaan laboratorium beserta alat-alat dan bahan yang diperlukan hanyalah akan merupakan suatu penerobosan (Kertiasa,2006).

Menurut Suyanta (2010) pengelolaan laboratorium akan berjalan dengan lebih efektif bilamana dalam struktur organisasi laboratorium didukung oleh Board of Management yang berfungsi sebagai pengarah dan penasehat. Menurut Munandar (2012), keberhasilan dalam pengelolaan laboratorium memerlukan manajemen yang baik yang meliputi perencanaan, operasional, kontrol, keberlanjutan. Keberhasilan disini sangat bergantung kepada pengelola beserta tenaga yang ada di laboratorium tersebut, seperti: staf peneliti, analisis, teknisi dan operator, serta jumlah dana yang tersedia.

Hasil penelitian sebelumnya yang telah dilakukan tentang kompetensi guru dalam pengelolaan laboratorium IPA pada beberapa SMPN di Kota Pekanbaru tahun Ajaran 2014/2015 mendapatkan bahwa secara umum, kompetensi guru sudah berada pada kategori efektif atau kompeten dengan persentase $84,35 \%$ sampai dengan 85,18\% (Jumiati, 2015). Akan tetapi, fakta di lapangan menunjukkan bahwa masih ada di beberapa sekolah dijumpai laboratorium IPA dengan fasilitas dan sarana prasarana laboratorium yang tidak lengkap. Rata-rata SMPN di kota Pekanbaru tidak memiliki laboran dan teknisi labor, sehingga pengelola atau kepala laboratorium IPA kewalahan dalam mengurus laboratorium IPA. Administrasi laboratorium masih ada yang belum lengkap dan kepala laboratorium atau pengelola laboratorium IPA masih ada yang belum pernah mengikuti pelatihan tentang pengelolaan laboratorium IPA. Selain itu juga berdasarkan hasil observasi diperoleh bahwa banyak ruangan laboratorium yang dimanfaatkan sebagai ruang kelas untuk proses pembelajaran, bukan diperuntukkan untuk kegiatan praktikum.

Selain itu, masih banyak sekolah menengah di Kota Pekanbaru yang belum memiliki laboratorium IPA/Biologi dengan peralatan dan bahan laboratorium yang lengkap. Ruang laboratorium masih banyak digunakan untuk proses pembelajaran sebagaimana halnya seperti di ruang kelas. Sampai saat ini, belum ada penelitian tentang profil laboratorium IPA/Biologi SMP Negeri di Kota Pekanbaru. Diharapkan setelah dilakukan penelitian tentang profil laboratorium dan kompetensi guru pengelola laboratorium IPA/Biologi di SMP Negeri di Kota Pekanbaru dapat memberikan informasi tentang deskripsi laboratorium dan kompetensi guru dalam pengelolaan laboratorium IPA/Biologi sehingga dapat dijadikan sebagai bahan evaluasi secara berkelanjutan bagi semua pihak terkait. Oleh karena itu, telah dilakukan penelitian dengan judul "Profil Laboratorium dan Kompetensi Guru 
Pengelola Laboratorium IPA di SMPN di Kota Pekanbaru Tahun Ajaran 2017/2018".

\section{METODE PENELITIAN}

Penelitian ini telah dilaksanakan mulai bulan Agustus 2017 sampai dengan selesai di sekolah-sekolah SMP Negeri yang terdapat di Kota Pekanbaru. Pemilihan sekolah sebagai subjek penelitian dilakukan dengan pertimbangan pencapaian tujuan yang ingin dicapai dalam penelitian. Metode penentuan sampel dilakukan dengan puoposive random sampling dengan harapan sekolah SMP Negeri terpilih dalam penelitian ini dapat memberikan gambaran mengenai kondisi dan kompetensi guru pengelola laboratorium IPA/ Biologi di sekolah-sekolah SMP Negeri di Pekanbaru.

Metode yang digunakan pada penelitian ini adalah metode survei. Penggalian data dilakukan melalui kuisioner dan wawancara dengan membuat sejumlah pertanyaan untuk diisi oleh responden. Wawancara dilakukan dengan cara tanya jawab secara langsung sesuai pendapat Sujarweni (2014). Demikian juga untuk profil laboratorium, dilakukan observasi secara langsung ke sekolah subjek penelitian. Metode survei digunakan untuk mengetahui deskripsi tentang kompetensi pengelolaan laboratorium IPA pada SMP Negeri di Kota Pekanbaru Tahun Ajaran 2016/2017.

Pada penelitian ini instrumen penelitian adalah lembar observasi tentang profil laboratorium dan kompetensi guru pengelola laboratorium, serta angket atau kuesioner, daftar centang, pedoman wawancara, dan pedoman pengamatan laboratorium IPA/Biologi. Data adalah seluruh informasi empiris dan dokumentatif yang diperoleh di lapangan sebagai pendukung ke arah konstruksi ilmu secara ilmiah dan akademis (Mukhtar, 2013).

Data yang diperoleh tentang profil laboratorium dianalisis secara deskriptif dengan teknik persentase, untuk selanjutnya dibandingkan dengan indikator menurut Permendiknas. Indikator tersebut dijadikan sebagai titik tolak untuk menyusun item-item instrumen yang dapat berupa pernyataan atau pertanyaan (Sugiyono, 2009). Skala yang digunakan untuk mengukur tingkat penilaian responden berupa metode skoring data menurut skala Likert yang berupa skala ordinal, menyangkut skala 1 sampai dengan 3. Penggunaan skala Likert dilakukan untuk suatu objek, dan pertanyaan yang cenderung mengekspresikan sikap yang menyenangkan, dan sebagian lagi pernyataan itu tidak menyenangkan (Nurhasan, 2011). Untuk menganalisis angket kompetensi pengelola laboratorium yang telah diperoleh maka peneliti mengubah data tersebut dalam bentuk persentase dengan menggunakan rumus berikut ini:

$$
P=-\quad x 100 \%
$$$$
\mathrm{N}
$$

Keterangan :

$\mathrm{P}=$ Angka presentase

$\mathrm{F}=$ frekuensi yang di cari persentasinya

$\mathrm{N}=$ Number of Cases (Jumlah frekuensi atau banyak individu) Sumber: Djamarah 2010).

\section{HASIL DAN PEMBAHASAN}

\section{Profil Laboratorium}

Data hasil penelitian tentang profil laboratorium diperoleh melalui observasi langsung di Laboratorium IPA/Biologi 8 SMP Negeri di Kota Pekanbaru dengan acuan lembar observasi yang disusun berdasarkan Permendiknas No 24 Tahun 2007 tentang sarana dan prasarana laboratorium IPA/Biologi sekolah menengah. Selain itu didukung dengan data hasil wawancara dan dokumentasi peneliti. Pada bagian ini juga dilakukan analisis dari pencatatan dokumen dan hasil wawancara. Dalam hal ini telah diperoleh informasi mengenai deskripsi profil laboratorium IPA/Biologi beberapa SMP Negeri di Pekanbaru Tahun ajaran $2017 / 2018$. Persentase hasil penelitian sesuai dengan observasi yang telah dilakukan dapat dilihat pada tabel tentang kelengkapan alat dan bahan laboratorium di 8 SMP Negeri di Kota Pekanbaru (Tabel 1).

Berdasarkan analisis data yang telah dilakukan, untuk variabel tentang kelengkapan alat dan bahan laboratorium IPA/Biologi terdiri dari beberapa sub- indikator tentang daya dukung fasilitas laboratorium biologi. Masing-masing indikator yang telah diamati yaitu pada: (1) fasilitas perabot; (2) fasilitas peralatan pendidikan; 
(3) fasilitas media pendidikan; dan (4) fasilitas perlengkapan lain.

Tabel 1. Kelengkapan Alat dan Bahan Laboratorium IPA/Biologi

\begin{tabular}{lcccccc}
\hline Sekolah & \multicolumn{3}{c}{ Kelengkapan alat dan bahan laboratorium IPA/Biologi } & Jumlah & $\begin{array}{c}\text { Rata-rata } \\
\text { (\%) }\end{array}$ \\
\cline { 2 - 5 } & $\begin{array}{c}\text { Fasilitas } \\
\text { Perabot } \\
(\%)\end{array}$ & $\begin{array}{c}\text { Peralatan } \\
\text { pendidikan } \\
(\%)\end{array}$ & $\begin{array}{c}\text { Media } \\
\text { Pendidikan } \\
(\%)\end{array}$ & $\begin{array}{c}\text { Perlengkapan } \\
\text { Lain (\%) }\end{array}$ & & \\
\hline SMPN 16 & 75 & 73 & 1 & 60 & 308 & 77 \\
SMPN 17 & 100 & 64 & 1 & 60 & 324 & 81 \\
SMPN 3 & 100 & 72 & 1 & 80 & 352 & 88 \\
SMPN 32 & 85 & 81 & 1 & 100 & 366 & 91,5 \\
SMPN 1 & 78 & 71 & 1 & 90 & 339 & 84,75 \\
SMPN 14 & 89 & 83 & 1 & 70 & 342 & 85,5 \\
SMPN 5 & 78 & 73 & 1 & 90 & 341 & 85,25 \\
SMPN 7 & 89 & 83 & 1 & 90 & 362 & 90,5 \\
\hline
\end{tabular}

Berdasarkan Tabel 1 di atas dapat dilihat bahwa SMPN 17 dan SMPN 3 Pekanbaru memiliki persentase kelengkapan alat dan bahan laboratorium tertinggi yaitu sebesar $100 \%$ untuk sub-indikator fasilitas perabot. Sedangkan SMPN 16 Pekanbaru memiliki persentase yang paling rendah yaitu sebesar $75 \%$. Secara keseluruhan, kedelapan sekolah yang diteliti dalam penelitian ini mempunyai rata- rata persentase kelengkapan alat dan bahan laboratorium IPA/Biologi sebesar $85,43 \%$ yang termasuk kategori baik sesuai dengan Permendiknas No 24 Tahun 2007 tentang sarana dan prasarana laboratorium IPA/Biologi di sekolah menengah pertama (Menteri Pendidikan Nasional, 2007). Sementara itu, untuk indikator peralatan pendidikan, SMPN 7 dan SMPN 14 Pekanbaru memiliki persentase kelengkapan paling tinggi yaitu sebesar $83 \%$, sedangkan SMPN 17 Pekanbaru mempunyai persentase terendah yaitu 64\%. Untuk sub-indikator perlengkapan lainnya, persentase kelengkapan alat dan bahan laboratorium yang paling besar diamati pada SMPN 32 yakni sebesar 100\%, dan yang paling rendah yaitu pada SMPN 16 dan SMPN 17 Pekanbaru yang masing- masing mempunyai persentase sebesar $60 \%$. Secara umum, pada subindikator media pendidikan yaitu papan tulis, keseluruhan sekolah yang diamati telah memiliki persentase tertinggi yaitu sebesar $100 \%$.

Deskripsi tentang lokasi dan ruangan laboratorium IPA/Biologi berdasarkan hasil penelitian yang telah dilakukan oleh peneliti di laboratorium 8 SMP Negeri di Kota Pekanbaru didapatkan bahwa umumnya telah sesuai dengan Permendiknas No 24 Tahun 2007 tentang sarana dan prasarana laboratorium IPA/Biologi. Ruang laboratorium di sekolah yang telah diamati umumnya cukup luas dan nyaman. Luas ruangan laboratorium untuk masing-masing sekolah yang telah diteliti di SMPN 17, SMPN 3, SMPN 4, SMPN 14, dan SMPN 7 Pekanbaru secara berturut-turut yaitu: $96 \mathrm{~m}^{2}, 120 \mathrm{~m}^{2}, 196 \mathrm{~m}^{2}, 210 \mathrm{~m}^{2}$, dan 280 $\mathrm{m}^{2}$.

Beberapa faktor yang mempengaruhi deskripsi profil laboratorium lainnya yaitu adanya beberapa kegiatan yang sedang dilakukan di sekolah. Hasil observasi di SMPN 16 dan SMPN 32 Pekanbaru didapatkan bahwa ruang laboratorium dalam kondisi renovasi juga memiliki ruangan yang cukup besar, namun di SMPN 16 tidak tersedianya ruang penyimpanan tersendiri dan air yang tidak berfungsi serta luas laboratorium yang relative lebih kecil dan terletak diantara dua ruang kelas dan wc siswa sehingga luas laboratorium tidak dapat diperbesar lagi. Berbeda halnya dengan SMP 32 Pekanbaru, walaupun dalam proses perbaikan memiliki ruang penyimpanan tersendiri namun karena barang masih banyak yang baru, susuanan alat dan bahan yang belum tersusun rapi, sumber air yang ada disekolah ini juga masih dalam keadaan rusak masih dalam perbaikan dan pencahayaan di dalam laboratorium sudah dilengkapi dengan listrik yang dapat mendukung berjalannya kegiatan praktikum.

Hasil pengamatan di SMPN 1 Pekanbaru menunjukkan bahwa ruang laboratorium 
digunakan untuk ruang kelas namun sebenarnya laboratorium cukup luas dan cukup untuk memfasilitasi 35 orang sampai dengan 40 siswa praktikan. Selain itu, di dalam laboratorium juga terdapat sumber air bersih dengan pencahayaan yang memadai. Hasil observasi di SMPN 14, SMP 7 dan SMPN 5 Pekanbaru menunjukkan bahwa ruang praktik siswa dan ruang penyimpanan alat dan bahan terpisah.

\section{Kompetensi Guru dalam Pengelolaan Laboratorium}

Angket yang diberikan kepada subjek penelitian berisikan item-item pertanyaan yang terdiri dari 13 indikator dengan 101 item pertanyaan. Setiap indikator dihitung persentasenya dari setiap item pertanyaan yang telah dijawab oleh subjek penelitian. Berdasarkan analisis data tentang kompetensi guru pengelola laboratorium IPA/Biologi di delapan (8) SMP Negeri di Kota Pekanbaru didapatkan beberapa aspek kompetensi guru pengelola laboratorium IPA/Biologi yaitu: kompetensi keperibadian, sosial, administrasi, manajerial, dan kompetensi profesional.

$$
\text { Kompetensi kepribadian dapat }
$$

ditunjukkan melalui sikap dewasa,mantap, dan berakhlak mulia serta komitmen terhadap tugas. Kompetensi sosial dapat terlihat dari kerjasama dan komunikasi yang dilakukan dengan pengelola laboratorium lainnnya. Kompetensi administrasi diperlukan dalam perencanaan kegiatan, jadwal kegiatan laboratorium, pembagian tugas bagi teknisi laboratorium, memantau sarana dan prasarana laboratorium, mengevaluasi kinerja teknisi dan pembuatan laporan kegiatan laboratorium. Kompetensi manajerial mencakup kegiatan pengembangan laboratorium dan mengatur pengelolaan kegiatan laboratorium. Sedangkan profesionalisme seorang pengelola laboratorium dapat ditunjukkan melalui paparan gagasan yang diberikan untuk kemajuan laboratorium demi kepentingan pendidikan di sekolah (KEMENAG, 2013).

Hasil penelitian menunjukkan bahwa kompetensi guru pengelola laboratorium berada pada kategori cukup kompeten sampai dengan kategori sangat kompeten. Secara keseluruhan, diperoleh rata-rata kompetensi guru pengelola sebesar $81,62 \%$. Berdasarkan PERMENDIKNAS No 26 Tahun 2008, persentase ini termasuk kategori kompeten. Hal ini menunjukkan bahwa secara umum guru-guru yang mengelola laboratorium IPA di SMP Negeri Kota Pekanbaru telah mampu mengelola laboratorium dengan baik.

Berdasarkan penelitian menunjukkan bahwa guru pengelola laboratorium IPA/Biologi SMP Negeri di Kota Pekanbaru yang diamati sudah berusaha untuk menunjukkan komitmen terhadap tugas khususnya dalam pengelola laboratorium biologi dengan memenuhi tugas-tugas mengelola laboratorium. Setiap guru semestinya memiliki tanggung jawab yang besar terhadap tugas yang diembannya. Apalagi tangung jawab tersebut sebagai kepala laboratorium. Setiap kepala laboratorium harus memiliki tanggung jawab terhadap tugasnya, seperti harus teliti, tekun dan berhati-hati supaya dapat terwujudnya kondisi yang nyaman dan lancer selama proses pembeljaran. Sehingga setiap pengguna laboratorium harus memiliki komitmen yang kuat dalam menjaga kondisi di dalam laboratorium.

Wawasan dalam mengelola laboratorium sangat penting bagi kepala laboratorium apalagi guru IPA maupun guru yang lainnya. Wawasan dalam pengelolaan laboratorium akan mempermudah munculnya ide untuk mengembangkan laboratorium. Serta kita dapat memiliki pengalaman dalam mengelola laboratorium, seperti halnya bekerja sama dengan pihak luar untuk mencari informasi tentang pengelolaan laboratorium yang dapat dijadikan acuan atau panduan dalam memperbaiki laboratorium yang sudah ada jika dijumpai kekurangan maupun permasalahan terkait pengelolaan laboratorium. Bekerja sama dengan pihak dinas pendidikan untuk mendapat alat dan bahan yang bagus untuk dijadikan sebagai alat proses pembelajaran berbasis praktikum juga perlu untuk dilakukan. Hal ini akan mendukung proses kegiatan praktikum yang optimal, sehingga akan menguntungkan pihak sekolah dan bekerja sama dengan kepala sekolah untuk memudahkan mengajukan proposal sesuai dengan kebutuhan yang diperlukan laboratorium.

Berdasarkan hasil penelitian tentang profil laboratorium dapat disimpulkan bahwa telah diperoleh melalui observasi langsung di 
Laboratorium IPA/Biologi di SMP Negeri di Kota Pekanbaru dengan acuan lembar observasi yang disusun berdasarkan Permendiknas No 24 Tahun 2007 tentang sarana dan prasarana laboratorium IPA/Biologi sekolah menengah. Hasil penelitian menunjukkan bahwa rata-rata persentase kelengkapan alat dan bahan laboratorium IPA/Biologi sebesar 85,43\% (termasuk kategori baik) dan deskripsi laboratorium IPA/Biologi sesuai dengan Permendiknas No 24 Tahun 2007 tentang sarana dan prasarana laboratorium IPA/Biologi untuk sekolah menengah pertama.

Berdasarkan hasil penelitian tentang kompetensi kemampuan guru pengelola laboratorium IPA/Biologi dalam mengelola laboratorium, dapat disimpulkan bahwa kompetensi guru pengelola laboratorium berada pada kategori cukup kompeten sampai dengan kategori sangat kompeten. Secara keseluruhan, diperoleh rata-rata kompetensi guru pengelola sebesar 81,62\% (termasuk kategori kompeten). Hal ini menunjukkan bahwa secara umum guruguru yang mengelola laboratorium IPA di SMP Negeri Kota Pekanbaru telah mampu mengelola laboratorium dengan baik.

\section{UCAPAN TERIMA KASIH}

Ucapan terima kasih disampaikan kepada Lembaga Penelitian dan Pengabdian Masyarakat (LPPM) Universitas Islam Riau sebagai pihak yang telah mendanai kegiatan penelitian ini. Selain itu juga kepada Bapak Sudarmi, S.Pd., M.Si. sebagai validator ahli pengelolaan pendidikan yang telah mendukung penuh terlaksananya penelitian ini.

\section{KESIMPULAN}

Dari hasil penelitian yang telah dilakukan, dapat diambil kesimpulan sebagai berikut: (1) Tingkat kelayakan Lembar Kegiatan Peserta Didik (LKPD) berbasis pembelajaran inkuiri terbimbing (guided inquiry learning) pada materi sistem ekskresi di kelas XI MAN 1 Medan T.P 2017/2018 berdasarkan penilaian dari ahli materi adalah sangat layak dengan persentase nilai sebesar 91,8\%; (2) Tingkat kelayakan Lembar Kegiatan Peserta Didik (LKPD) berbasis pembelajaran inkuiri terbimbing (guided inquiry learning) pada materi sistem ekskresi di kelas XI MAN 1 Medan T.P
2017/2018 berdasarkan penilaian dari ahli pembelajaran adalah sangat layak dengan persentase nilai sebesar 93,75\%; (3) Tingkat kelayakan Lembar Kegiatan Peserta Didik (LKPD) berbasis pembelajaran inkuiri terbimbing (guided inquiry learning) pada materi sistem ekskresi di kelas XI MAN 1 Medan T.P 2017/2018 berdasarkan penilaian dari guru biologi adalah sangat layak dengan persentase nilai sebesar 87,56\%; (4) Tingkat kelayakan Lembar Kegiatan Peserta Didik (LKPD) berbasis pembelajaran inkuiri terbimbing (guided inquiry learning) pada materi sistem ekskresi di kelas XI MAN 1 Medan T.P 2017/2018 berdasarkan penilaian dari siswa adalah baik dengan persentase nilai sebesar 76,47\%; (5) Tingkat kemampuan berfikir kritis siswa kelas XI MAN 1 Medan T.P 2017/2018 setelah menggunakan Lembar Kegiatan Peserta Didik (LKPD) berbasis pembelajaran inkuiri terbimbing (guided inquiry learning) pada materi sistem ekskresi adalah cukup baik dengan persentase nilai sebesar 67,3\%; (6) Ketuntasan belajar klasikal siswa kelas XI MAN 1 Medan T.P 2017/2018 setelah menggunakan Lembar Kegiatan Peserta Didik (LKPD) berbasis pembelajaran inkuiri terbimbing (guided inquiry learning) pada materi sistem ekskresi adalah tuntas karena sudah memenuhi standar ketuntasan minimal yang telah ditetapkan sekolah dengan persentasi nilai sebesar $86,11 \%$.

\section{DAFTAR PUSTAKA}

Hamalik, O. 2011. Kurikulum dan Pembelajaran. PT Bumi Aksara: Jakarta.

Jumiati. 2015. Kompetensi Guru dalam Pengelolaan Laboratorium IPA di SMPN di kota Pekanbaru Tahun ajaran 2014/2015. Skripsi. Program studi Pendidikan Biologi Universitas Islam Riau: Pekanbaru.

KEMENAG. 2013. Kompetensi Sosial Dan Kompetensi Kepribadian Tenaga Kependidikan Laboratorium

Sekolah/Madrasah. KEMENAG RI: Jakarta.

Kertiasa, N. 2006. Laboratorium sekolah dan pengelolaannya. Pudak Scientific: Bandung.

PERMENDIKNAS. 2007. Peraturan Menteri Pendidikan Nasional Republik Indonesia Nomor 24 Tahun 2007 Tentang Standar Sarana Dan Prasarana Untuk Sekolah 
Dasar/Madrasah Ibtidaiyah (Sd/Mi), Sekolah Menengah Pertama/Madrasah Tsanawiyah (Smp/Mts), Dan Sekolah Menengah Atas/Madrasah Aliyah (Sma/Ma). PERMENDIKNAS: Jakarta.

PERMENDIKNAS. 2008. Peraturan Menteri Pendidikan Nasional Republik Indonesia Nomor 26 Tahun 2008 Tentang Standar Tenaga Laboratorium Sekolah/Madrasah Dengan Rahmat Tuhan Yang Maha Esa Menteri Pendidikan Nasional. PERMENDIKNAS: Jakarta.

Mukhtar. 2013. Metode Penelitian Deskriptif Kualitatif. GP Press Group: Jakarta.

Munandar. 2012. Budgeting: Perencanaan kerja, Pengkoordinasian Kerja dan Pengawasan Kerja. Bpfe: Yogyakarta.

Nurhasan. 2011. Tips Praktis Menjaga Kesehatan dan Kebugaran. ABIL Pustaka: Gresik.

Sugiyono. 2009. Metode Penelitian Administratif. Raja Grafindo Persada. Jakarta. Susanto. A. 2014. Teori Belajar dan Pembelajaran di Sekolah Dasar. hal. 208. Kencana: Jakarta.

Sujarweni, V.W. 2014. Metodologi Penelitian. Pustaka Baru Press: Yogyakarta.

Suyanta. 2010. Manajemen operasional laboratorium. Jurusan Pendidikan Kimia FMIPA Universitas Negeri Yogyakarta: Yogyakarta. 